\title{
Non-Verbal Language Expressed in Jokowi’s Speech
}

\author{
Sondang Manik ${ }^{1}$ \\ ${ }^{1}$ English Department, Language and Arts Faculty, HKBP Nommensen University, Medan North Sumatra, \\ Indonesia \\ Correspondence: Sondang Manik, Jl.Sutomo no 4A, Medan 20234, Indonesia. Tel: 62-61-452-2922. E-mail: \\ sondang_man1k@yahoo.com
}

Received: March 17, 2015 Accepted: April 10, 2015 Online Published: May 30, 2015

doi:10.5539/ijel.v5n3p129 URL: http://dx.doi.org/10.5539/ijel.v5n3p129

\begin{abstract}
Non-verbal communication is one of the key aspects of communication. Non-verbal communication can even alter a verbal message through mimics, gestures and facial expressions, particularly when people do not speak the same language. It is important to know and use non-verbal aspects when we communicate with someone or when we deliver our speech in front of people. The data are taken from some of Jokowi's speeches. This is a qualitative research, from the recorded data. The speech is identified and analyzed and the writer concludes that Jokowi uses non-verbal aspects in his speech. Five kinds of kinesics are used in everyday communication, namely, emblems, illustrators, affect displays, regulators and adaptors. Some of the aspects make him look so nervous, but he can balance it by laughing or grinning to make the speech not monotonous and attract the audience. He speaks mostly slowly which would make the audience easier to understand the speech. Everybody has their own style in delivering their speech, and this is the Jokowi's style in delivering his speech. After analyzing the speech, the characteristics of Jokowi's non verbal language in his speech can be drawn as follows. He uses Paralinguistics, Oculesics, Appearance, Proxemics and Kinesics. He always uses his pointing finger, to show the serious intention, in intonation of his Javanese dialect and starts with a religious greeting, with a big smile, to show his friendly and humble character.
\end{abstract}

Keywords: non-verbal communication, Kinesic, facial expression

\section{Introduction}

Communication is a crucial factor in human life. Through the communication people want to reveal and emphasize their opinions, ideas, and thought. They communicate with other people to exchange knowledge and information, convey their opinion, thought and argument and make a good relationship with others. Through communication people express, emphasize and clarify the meaning. Communication has been called the transfer of meaning from one mind to another, because meanings exist in the human mind and they cannot be shared or communicated except through some external vehicle. The human body is capable of making sounds and movements which in turn can create a system of vehicles for sharing inner meanings and ideas with others

Everyone uses speech to express their feeling or their meanings. Presidents, Cabinet Minister and actress use the speech to convey their opinion or their message to the public. Speech is also used by the students to convey their opinion and information.

Doing a speech means the utterance has influences to make the other interested to respond, so people especially the presidential candidate can build good conversation with the audience or people by the right intonation, right posture, good eye contact, and etc. The candidate conveys their idea, suggestion, and the message, using non verbal language. The real application of the non verbal is also applied by any speaker.

Verbal communication includes spoken, oral, and unwritten way of communicating. Ronald S. Tolentino (2011) states that "Non-verbal communication plays a much larger part in how we communicate and trained mediators need to pay much more attention to the non-verbal cues of the disputing parties. Non-verbal cues also convey mood, feelings, attitude, emotion, state of mind, give support for spoken words and provide immediate feedback to messages received." But the writer is more interested to analyze the non-verbal communication in this research, because there are some differences of non-verbal communication that are used by people everyday. They use difference posture, hand gesture, eye contact, or mimic. 
Semiotics is concerned with everything that can be taken as a sign. Semiotics involves the study not only of what people refer to as 'signs' in everyday speech, but of anything which 'stands for' something else. In a semiotic sense, signs take the form of words, images, sounds, gestures and objects. Umberto Eco (1976, p. 7) states that semiotics is the study of such signs. In general terms, such elements that codify meaning are called signs.

Research questions:

Based on the explanation above, the writer is interested to analyze the non verbal language expressed in Jokowi speech. The reason for choosing this topic is to find out the types of non-verbal communication and the most dominant types of non-verbal communication that are used in the Jokowi's speech.

The writer focuses on the scope of this study to find out the kinds of non-verbal language based on Ronald S. Tolentino theory; Kinesics, Paralinguistic's, Oculesics, Appearance and Proxemics. The writer chooses four types of non-verbal communication: they are Kinesics, Paralinguistics, Oculesic, and Proxemics.

The writer focuses on the non-verbal communication expressed by Jokowi's speech.

This study is expected to be useful for the writer to improve her knowledge to understand about the non-verbal language on a speech; useful for readers to enrich knowledge, specifically, about non-verbal language; to make reader easier to understand the meaning of non-verbal and how to use it correctly. It will be a contribution for students or lecturers who are interested in doing further researh about non verbal language, to understand that speech can be expressed through non-verbal communication.

\section{Semiotics}

Umberto Eco, states that "semiotics is concerned with everything that can be taken as a sign" (Eco, 1976, p. 7). Semiotics involves the study not only of what we refer to as 'signs' in everyday speech, but of anything which 'stands for' something else. In a semiotic sense, signs take the form of words, images, sounds, gestures and objects. Contemporary semioticians study signs not in isolation but as part of semiotic 'sign-systems' (such as a medium or genre). They study how meanings are made and how reality is represented. Saussure saw linguistics as a branch of 'semiology' states that linguistics is only one branch of this general science [of semiology]. The laws which semiology will discover applicable in linguistics as far as we are concerned. The linguistic problem is first and foremost sociological. If one wishes to discover the true nature of language systems, one must first consider what they have in common with all other systems of the same kind. In this way, light will be thrown not only upon the linguistic problem. By considering rites, customs etc. as signs, it will be possible, we believe, to see them in a new perspective. The need will be felt to consider them as sociological phenomena and to explain them in terms of the laws of sociology. (Saussure, 1983, pp. 16-17)

At around the same time as Saussure was formulating his model of the sign and of 'sociology' (and laying the foundations of structuralism methodology), across the Atlantic closely related theoretical work was also in progress as the pragmatist philosopher and logician

Daniel Chandler (2001, p. 29) states that formulated his own model of the sign, of 'semeiotic [sic]' and of the taxonomies of signs. In contrast to Saussure's model of the sign in the form of a 'self-contained dyad', Peirce offered a triadic (three-part) model consisting of:

1. The represent men: the form which the sign takes (not necessarily material, though usually interpreted as such) — called by some theorists the 'sign vehicle'.

2. An interpret ant: not an interpreter but rather the sense made of the sign.

3. An object: something beyond the sign to which it refers (a referent).

A sign [in the form of a represent a men] is something which stands to somebody for something in some respect or capacity. It addresses somebody, that is, creates in the mind of that person an equivalent sign, or perhaps a more developed sign. That sign which it creates I call the interpret ant of the first sign. The sign stands for something, its object. It stands for that object, not in all respects, but in reference to a sort of idea, which I have sometimes called the ground of the represent amen.

Mahfouz A. Adedimeji states that the methodical and practical definition of semiotics sees "it as the application of linguistic methods to objects other than natural language" which means that semiotics is an approach of considering anything as constructed similar to language. This approach is also adopted by The New Lexicon Webster's Dictionary of the English Language (1987) which defines semiotics as a study of patterned human communication behavior including auditory/vocal and facial expression, body talk (kinesics) touch (polemics), signs, symbolic (sociology). 


\subsection{Nonverbal Language}

Roland S. Tolentino (2011) states that non-verbal communication plays a much larger part and trained mediators need to pay much more attention to the non-verbal cues of the disputing parties. Kifayat Aghayeva states that non-verbal communication is one of the key aspects of communication. Its diverse functions include repeating, accentuating, complementing and contradicting a verbal message. This type of communication also normalizes relations, such as non-verbal cues conveying when a person should speak or not speak. Finally, non-verbal communication can even alter a verbal message through mimics, gestures and facial expressions, particularly when people do not speak the same language.

Paul Cobley (2001, pp. 14-17) states that terminological note might be in order at the outset. The word 'language' is sometimes used in common parlance in an inappropriate way to designate a certain nonverbal communicative device. Nonverbal communication takes place within an organism or between two or more organisms. Within an organism, participators in communicative acts may involve-as message sources or destinations or both - on rising integration levels, cellular organelles, cells, tissue, organs, and organ systems. Another interesting sort of nonverbal communication takes place during conducting, which can be defined as involving the elicitation from an orchestra with the most appropriate minimum choreographic gestures of a maximum of acoustical results. In a public setting, the conductor connects not just with the members of the orchestra but also with the audience attending the concert. The gestures shaped by his entire upper body equipment - including hands, arms, shoulders, head, eyes - are decoded by the onlookers through the visual channel, transformed by the players into sound, which is then fed back to the audience.

\subsection{Types of Nonverbal Language}

Roland S. Tolentino (2011) describes that there are five types of nonverbal language. They are:

\subsubsection{Kinesics}

The scientific study of the use of body movement that accompanies speech is referred to as kinesics. The key components of kinesics are gestures, facial expressions, eye behavior, and posture. There are also five (5) kinds of kinesics that are used in everyday communication, namely, emblems, illustrators, affect displays, regulators and adaptors.

\section{1) Emblems}

Emblems are defined as body movements that substitute for words and phrases. Examples of these are the first finger on an upright position placed in front of the mouth universally means "quiet". An open hand held up usually means "stop". The "Victory Sign" is commonly displayed by first and second finger extended to form a letter "V" and the third and fourth fingers are curled with the thumb palm with the palm facing outside. However, the meaning of emblems usually vary from culture to culture. The thumbs up generally mean "OK.", "Approved." or "Right on!" or to indicate something that is liked or appreciated. In, Afghanistan, Iran, Nigeria and some part of Italy and Greece, the thumbs up sign is an obscene insult, especially when combined with a sweep of the arms.

\section{2) Illustrators}

Illustrator, on the other hand accompany and reinforce verbal messages. A few examples of illustrators are nodding when saying yes, shaking the head when saying no, and pointing a finger to emphasize an argument. Illustrators tend to be more universal in meaning than other kinds of body movement but they can also be misinterpreted. Even the simple nod may be differently interpreted by a man and a woman. A man may nod to mean "Yes, I heard you" but the woman may take it to mean as an agreement and support for her idea. Affect displays which refer to the nonverbal displays of the body or face that carry an emotional meaning or display affective states. In other words, affect displays show the mood that the person is in.

\section{3) Aspect Display}

Affect Displays are often spontaneous such as the breaking out in a grin when happy or amused, frowning when displeased and the slamming the hand on the table when a disputant is angry or slamming the door when an angry person leaves the room. Observe how the disputants stare and threaten each other during the storytelling phase of the mediation process.

\section{4) Regulator}

Regulators, as the fourth category of kinesics, are nonverbal messages which control, regulate or influence the flow and pace of communication. Nodding of the head to indicate understanding or to encourage the party to continue talking, moving away to signal the desire to terminate the communication or looking away to show 
disinterest. Another example is raising a finger or hand to indicate the desire to speak or sitting upright as well as leaning forward to show interest in the discussion and a desire to be involved.

\section{5) Adaptors}

The final area of kinesics is adaptors. Adaptors are low level awareness behaviors to meet a personal need as one adapts to a specific situation. Some experts believe that adapters are use at times to relieve tension. Some even call adapters as "nervous habits" or "involuntary ticks". Examples of adapters are the tapping of the pen or of the fingers, pulling of the ear, twisting of the hair, scratching of the nose or of the head, pushing of eyeglasses up the nose, shaking of the leg or foot and the like.

\subsubsection{Paralinguistic's}

Ronald S. Tolentino (2011) states that paralinguistic's refers to the nonverbal vocal expressions of a person. According to experts, voice set and vocalization are the two dimensions of the voice. Voice set is the information that may be gathered from the sound of the voice such as gender, maturity and mindset. On the other hand, vocalizations are non-word sounds that usually reveal emotion such as laughing, crying, yawning, etc. Paralinguistic's communication has several contributing factors. Speed (rate), Volume, Rhythm, Pitch, Inflection, Quality and Intensity are just a few of these factors.

\section{(1) Speed}

Speed refers to the rate of speech. A fast rate of speech and a fast rate of being able to respond have been traditionally correlated to self-assurance and composure. Thus, a person who talks fast is often seen as confident and dominating. However, the downside to fast talkers is that they are often perceived as poor listeners especially when the content of the response given is off target and seemingly irrelevant. To establish a more subtle connection with the disputants and vocal rapport with them, it thus recommended that mediators talk in the similar rate as that of the disputant the mediator is conversing with.

\section{(2) Volume}

Volume, as one of the factors of paralinguistic's communication, refers to the loudness of the sound. A weak voice usually indicates a lack of confidence, tepidness and hesitancy while assertiveness, confidence and boldness are reflected in a louder speech. Since a mediator must be in control of the mediation process, it is important for a mediator to speak with sufficient volume as not to appear timid and hesitant.

\section{(3) Rhythm}

Rhythm refers to the pattern of sound that characterizes a language, dialect or accent. All international languages have peculiar rhythms unique to each particular language. A Malaysian speaks at a different rhythm and speed from that of a Filipino. When speaking in the global language of English, a person will generally speak English using a rhythmical pace similar to that of their native language. A person from China will likely speak using a rhythmical pace similar to their native Chinese language rhythm. Since the Chinese language has a very fast rhythm and speed, it is expected that a person from China will likely speak English faster than the other nationalities. With this in mind, irrespective of the mediator's native language, it is advisable for a mediator to speak in a rate and rhythm similar to the speech rate and rhythm of the slowest speaking person. By doing so, communication and connection on a paralinguistic level between the mediator and the disputant will be so much easier.

\section{(4) Pitch}

Pitch refers to the frequency or level of a sound. Lower pitches are often associated with greater credibility, maturity and authority while a high-pitched voice appears to child-like, excitable and at times, immature. Often times, mediators are advised to speak a lower pitch to appear more authoritative, calmer and more credible. However, it is important to note that the pitch a mediator uses to speak in during a mediation session should be closer to the one that is most natural his or her vocal range. Forcing one's voice to speak at a low pitch often results in loss of vocal power and focus.

\section{(5) Inflection}

Inflection or vocal variety refers to variations in pitch or musical quality of the voice. Inflection is best illustrated by the almost sing-song variations of pitch that a storyteller makes while reading a book to children. Caution must be made in the use of too much inflection in the mediation context since it may undermine the credibility of a mediator. A mediator must have some degree of inflection in his speech to maintain the interest of the disputants in what he is saying. With a little inflection, a mediator will be perceived as charismatic and credible. 


\section{(6) Quality}

Quality, in paralinguistic's communication, usually refers to the character of the vowel sound and the distinctive tone people make when speaking. It is that distinctive vocal characteristic of the voice that differentiates one voice from another. Mediators should be aware that the quality of their voices or speech plays an important role in the conduct of their mediation sessions. A disputant is less likely to listen to the mediator when his speech or voice is small, thin, throaty, nasal, or hoarse. Good quality makes listening to the mediator so much easier and pleasurable. It is thus important for a mediator to get a realistic idea of how he sound by making a recording of his speech and getting feedback from trusted persons on vocal quality.

\section{(7) Intensity}

Intensity refers to the strength, power or force of the speech. Intensity is indicative of the passion and level of commitment of the speaker and reveals the emotions behind the spoken words. When a mediator quickly and established vocal rapport with the disputants when he matches and mirrors the vocal characteristics of a disputant without mockery coupled with a genuine intention to authentically connect with them. This in turn leads to greater understanding and more efficient paralinguistic communication (Tolentino, 2011).

\subsubsection{Proxemics}

Proxemics refers to the amount of space around a person or between two persons. Communicating with others by virtue of the relative positioning of your bodies is called Proxemic communication. Paul Cobley (2001:21) states that The study of spatial and temporal bodily arrangements (sometimes called proxemics) in personal rapport, the proper dimensions of a cage in the zoo or of a prison cell, the layout of offices, classrooms, hospital wards, exhibitions in museums and galleries, and a myriad other architectural designs - involves the axiology of volume and duration. Roland S. Tolentino (1966) states that four key zones of personal space around our bodies and classified them as:

(1) Intimate: touching to 10 inches. For close friends and family.

(2) Casual-personal: 18 inches to four feet: Informal conversation with friends.

(3) Social-consultative: four to twelve feet: formal transactions.

(4) Public: Addressing groups of people.

The distances can vary from person to person. In terms of personality, extroverts tend to have smaller distances compared to introverts usually want to keep their distance. In mediation, an understanding and application of proxemics by the mediator is important. The mediator must sit equidistant from both of the parties. Sitting closer to one of the parties usually generate the perception of bias or partiality. The mediator must also sit closer to the disputants than to their counsels or support persons. In this manner, the mediator is able to converse with the disputing parties directly without the risk of being cut off by their counsels or support persons. Vertical space between persons may indicate the level of dominance. Mediators should create a safe and open environment for the parties in mediation. In order to create such an atmosphere, mediators are often advised to sit at the same eye level as those of the parties. Parties should also be seated at identical chairs so that one party does not sit higher than the other. The Mediator must also be aware of the relative heights of the disputants and to make a taller disputant sit at a lower chair and a shorter party at a higher chair. The goal is to allow the parties to sit at equal eye level to avoid the setting of dominance. To this end, this author has a personal preference for adjustable seats in the mediation rooms since it allows the author to adjust the heights of the seats to in accordance with the heights of the parties.

\subsubsection{Oculesics}

The study of eye contact in nonverbal communication is called "Oculesics". There is eye contact when two people look at each other's eyes at the same time. Eye aversion, on the other hand, is defined as the avoidance of eye contact. It has been found that people indicate their interest through the use of their eyes. Eye contact can provide positive or negative mood signs to the observer. However, the frequency, interpretation and appropriateness of eye contact differ from culture to culture. In the Western World, direct eye contact lasting 2 seconds is preferred. A person who avoids eye contact is considered insecure, incompetence, untrustworthy and may lack confidence. However, any eye contact longer than 2 seconds is regarded as "staring" and the person who stares is considered "rude". Prolonged eye contact between men and women is a sign of interest and may even be interpreted as being sexually suggestive. In Asia, indirect eye contact is preferred. It is a sign of bad manners, aggression and hostile to have prolonged eye contact. People from Japan direct their gaze to the throat area and lower their eyes as a sign of respect. In the Islamic faith, while eye contact between males is allowed, 
this is not the same case for eye contact between members of the opposite sex unless the parties are legitimate spouses or family members. After the initial eye contact, men lower their gaze when speaking with women. Any prolonged eye contact with the opposite sex is considered highly inappropriate and disrespectful.

Mediators, when dealing with Asians, are encouraged to make appropriate eye contact or avoid eye contact when dealing with members of the opposite sex belonging to the Islamic Faith. However, where the disputants belong to Western countries, then eye contact is important. When addressing a number of disputants, it is often advisable to look at everyone.

\subsubsection{Speech}

According to The Linguistics Encycopledia (1991, p. 204) define speech is the production of meaningful utterances in a language. Speech is a formal talk given to audience that a show case where the speaker becomes the center of attention because the speaker is the source of information. Speech is consisting of three (3) important parts: there are the beginning, the middle and the end.

The beginning is called an introduction of speech. An introduction should be interesting, to the point and not too long. The beginning tells the audiences about she/he will say in that speech. The goal of the beginning is to catch the audience's attention and interest and reveal the topic of the speech. There should be a few points and avoid having too many topics and make them strictly relevant to the purpose of the speech.

The middle is called the body of the speech that explains about the main point of the speech. In the body, the speaker speaks about each point in detail. Some evidence or information will be needed to support the main points.

The end is called the conclusion of the speech. In concluding the speech, it's part of speech in summarizing the major points of the topic. This should sum up the key of the topic what want to speech.

\subsection{Previous Research}

Yongming Shi \& Si Fan (2010) in their study of An Analysis of Non-verbal Behaviour in Intercultural Communication has described that Nonverbal communication is considered as an indispensable component of human interaction and it bears close relationship with culture. Each culture has a set of norms regarding the appropriateness of different types of body language and paralinguistic factors. However, the nonverbal communication is often overlooked in second language teaching programs. The results of the study has a potential to help English Foreign Language teachers in China to better understand the current difficulties encountered by Chinese background students in intercultural communications. This study also suggests including knowledge of nonverbal communication into EFL teaching so as to enable English learners to become fully competent in the targeted language, because nonverbal communication is used in everyday communication, and it is one of the prerequisites to acquire intercultural communicative competence. In this study the Data were collected through interviews and the participants' reflective journals.

This study involves the participation of eight Chinese background students from the Faculty of Educational the University of Tasmania. All the data were analysed using constructivist grounded theory which involves a coding process, open coding, axial coding and selective coding. Through the data analysis process, it was found that all the participants view the nonverbal communication as an important component of human communications.

Haiyan Wang (2009) has described that nonverbal communication is important to interpersonal communication. It is impossible to list all the nonverbal behaviors, for nonverbal communication is so complicated. Because of the differences in gender, occupation, class, race, culture and so on, the messages and meanings of nonverbal behaviors become more complex. Especially the effect of culture, in different cultures, the same nonverbal behavior even transmits just opposite messages and meanings.

The study on nonverbal communication has great effect of guidance on practice. Through the study on nonverbal communication, people know what and how people should do in certain communication circumstances, thus people can improve our nonverbal behaviors. In recent years, the use of nonverbal communication methods has new development. If people want to tell the person that they are happy, they can send an emotion picture with a smiling face, and then the person will understand their mood. This way is more interesting and vivid than characters. In all, as long as people can comprehend nonverbal communication comprehensively and understand the different messages and meanings of various nonverbal behaviors under the effect of different factors, it is not hard to behave properly and make correct judgment to other people's nonverbal behaviors, thus the aim of improving interpersonal communication can be reached. In the future, people have reasons to believe that 
nonverbal communication will get inconceivable new development, bring us more surprises and change the traditional communication patterns more greatly.

Nonverbal language is the way of people to communicate without words. Nonverbal language is very helpful for people to communicate. Without realizing it every day every person always uses nonverbal language. It was very helpful for every person to express their intent and feelings in other ways that are easily understood. Many things can't be expressed in words; finally are expressed by using nonverbal language. Like using facial expressions when happy or sad, or using your hands to explain something, there are many more ways to communicate with nonverbal language. Even when people talk or speech in front of many people, they also use the non-verbal language. If people pay attention to other people during a speech or speaking, of course they will find a lot of use of the non-verbal language; it can be seen from the change in facial expression, tone and volume changes, or visible from the movement of his body. Here is the conceptual framework of the nonverbal language that is expressed by students' speech.

Here is an important division of nonverbal language:

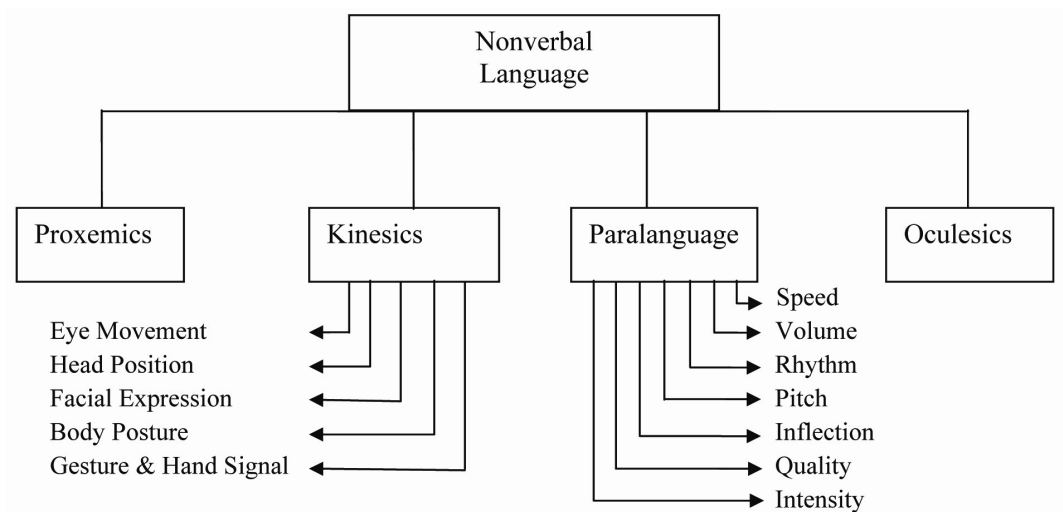

Feature 1. Division of non-verbal language (Tolentino, 2011)

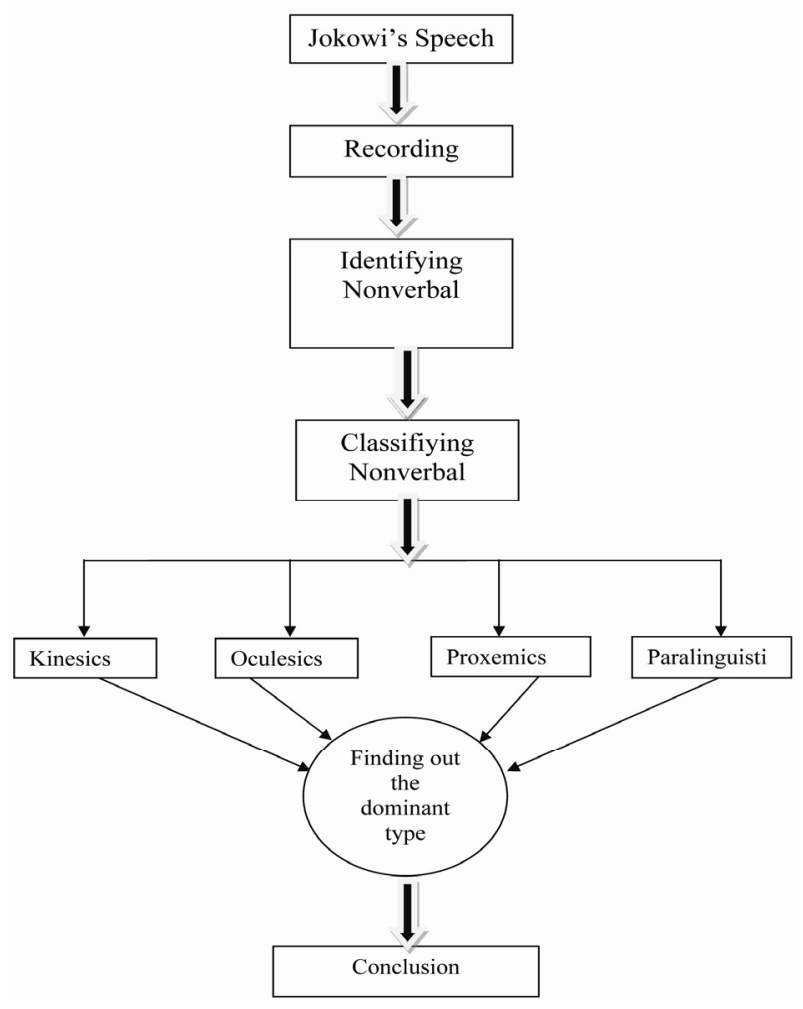

Figure 2. The conceptual framework of analyzing nonverbal language (Manik, 2015) 


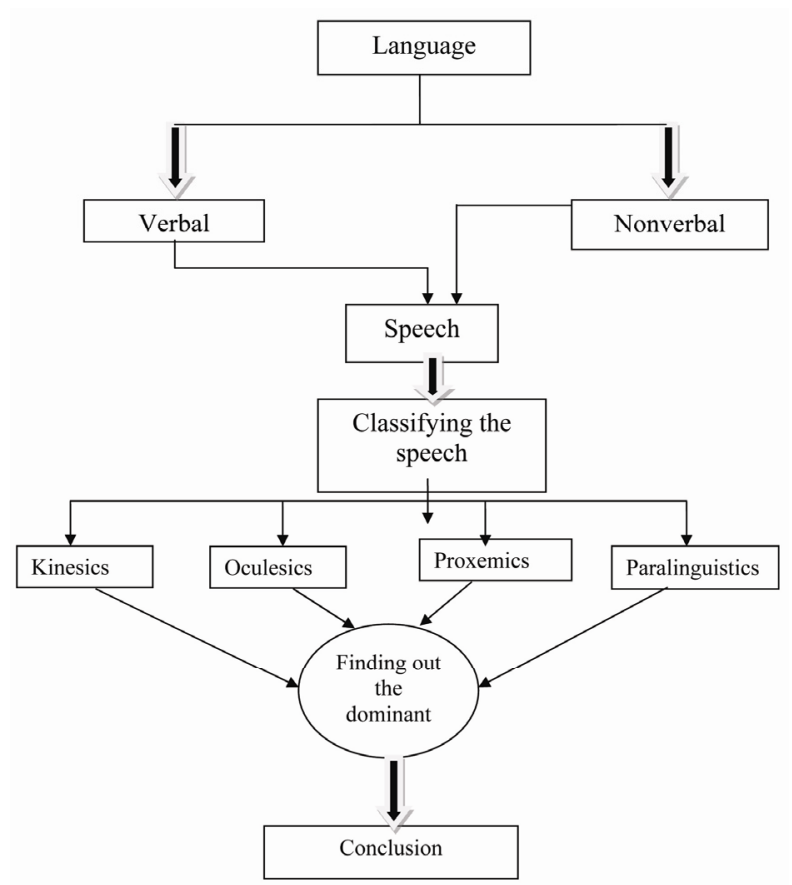

Figure 3. The theoretical framework of analyzing nonverbal language expressed in Jokowi speech

\section{Research Design}

Research design is the way or all the strategies to find out and to get the data which is needed in the research. This study used descriptive qualitative method. Descriptive qualitative design does not intend to find new theory but to find new evidences to prove the truth theory. Since this study is descriptive research, the writer attempted to describe the use of nonverbal language and purposes of this nonverbal language.

The subject of this research non-verbal language find in the students' speech. The speech will be taken from the youtube. The writer chooses three speeches; they are a speech about Indonesian Independence Day, a speech about the effect of Internet for our life, and a speech about the environment.

The data are analyzed by following these procedures, namely:

1) listening to and watch Jokowi's speech.

2) recording the Jokowi's expression and transcribing the data from the recording.

3) identifying the types of non-verbal communication that are expressed by Jokowi in its language function.

4) classifying non-verbal into their types: kinesics, paralinguistics, oculesics and proxemics.

5) counting the types of non-verbal communication.

6) converting the frequency of each kind of non-verbal into percent by following formula.

$$
\mathrm{X}=\frac{F}{N} X 100 \%
$$

Where $\mathrm{X}=$ percentage of each types of non-verbal

$$
\begin{aligned}
& \mathrm{F}=\text { frequency of each types of non-verbal } \\
& \mathrm{N}=\text { amount frequency off all types of non-verbal }
\end{aligned}
$$

7) finding out the most dominant types of non-verbal communication as the result.

\section{Data}

To complete the research the writer lists the data that have been chosen to be analyzed. The Data are taken from Jokowi previous speech from Youtube. 
Table 1. Data

\begin{tabular}{|c|c|c|}
\hline No & Date & Title \\
\hline 1 & September 19th 2013 & Jokowi delivers his speech to celebrate Tahun Soegeng Sarjadi School of Gonvernment \\
\hline 2 & 9th July 2014 & After the announcement of Jokowis' winning as a new President by Quick Count at Monas Jakarta \\
\hline 3 & 22 July 2014 & $\begin{array}{l}\text { On the victory of Jokowi Widodo with his partner Jusuf Kala to be President and Vice President } \\
\text { of Indonesia }\end{array}$ \\
\hline 4 & 22 Agustus 2014 & Halal Bihalal Partai Nasdem dalam Presiden terpilih Joko Widodo \\
\hline 5 & 22 September 2014 & Jokowi's victory speech and Jusuf Kalla's speech at Phinisi Board \\
\hline 6 & 20 Oktober 2014 & The Enthronement event for celebrating the seventh President of RI \\
\hline 7 & 20 October 2014 & The Speech of Inaugural Celebration \\
\hline
\end{tabular}

After listening to the speech the writer writes down the text of the speech (at the appendixes), identifies the types of non-verbal communication that are expressed by Jokowi in its language function and classifies non-verbal into their types: kinesics, paralinguistic's, oculesics and proxemics.

This speech was given in Garden Terral Four Seasons Hotel, Jakarta, on Thursday, September 19th 2013. The audience is the important people (male and female). Jokowi gave a speech in front of the audience. The occasion that Jokowi delivered his speech is to celebrate "Tahun Soegeng Sarjadi School of Government" (School anniversary of Soegeng Sarjadi ). In this speech, Jokowi talked about how his style to be a leader, and described his plan to make Indonesia better.

\section{1) Kinesics}

There are also five kinds of kinesics that are used in everyday communication, namely, emblems (1), illustrators (2), affect displays (3), regulators (4) and adaptors (5).

Table 2. The identification of Kinesics

\begin{tabular}{|c|c|c|c|c|c|c|c|c|}
\hline $\begin{array}{l}\text { No. } \\
1\end{array}$ & $\begin{array}{l}\text { Min/Sec. } \\
02: 30\end{array}$ & $\begin{array}{l}\text { Kinesics } \\
\text { Holding his } \\
\text { hand }\end{array}$ & 1 & 2 & 3 & 4 & $\begin{array}{l}5 \\
\checkmark\end{array}$ & $\begin{array}{l}\text { Explanation } \\
\text { By holding his hand he may } \\
\text { feel comfort in delivering } \\
\text { his speech. }\end{array}$ \\
\hline 2 & $\begin{array}{l}02: 47,0 \\
12: 47\end{array}$ & Grin/Laughing & & & $\checkmark$ & & & $\begin{array}{l}\text { Jokowi mostly laughs or } \\
\text { grins to make the speech not } \\
\text { monoton, to attract the } \\
\text { audience. }\end{array}$ \\
\hline 3 & 03 & $\begin{array}{l}\text { To tidy his } \\
\text { sleeves }\end{array}$ & & & & & $\checkmark$ & $\begin{array}{l}\text { This kind of thing makes } \\
\text { Jokowi seem not confident. } \\
\text { He holds his shirt many } \\
\text { times. }\end{array}$ \\
\hline 4 & $03: 35$ & $\begin{array}{l}\text { He bend his } \\
\text { fingers while } \\
\text { speaking }\end{array}$ & & & & & $\checkmark$ & $\begin{array}{l}\text { This kind of thing also looks } \\
\text { like Jokowi is nervous. }\end{array}$ \\
\hline 5 & $04: 58$ & $\begin{array}{l}\text { Pointing a } \\
\text { finger }\end{array}$ & $\checkmark$ & & & & & $\begin{array}{l}\text { Pointing his finger shows } \\
\text { that Jokowi means his } \\
\text { words and he wants to show } \\
\text { audience that it is the truth. }\end{array}$ \\
\hline
\end{tabular}




\begin{tabular}{lll}
\hline 6 & $\begin{array}{l}\text { Hold his shirt } \\
\text { button }\end{array}$ & $\begin{array}{l}\text { This kind of kinesics makes } \\
\text { Jokowi seem not confident. }\end{array}$ \\
& $\begin{array}{l}\text { Shaking his } \\
\text { right hand (zig- } \\
\text { zag) }\end{array}$ & $\begin{array}{l}\text { He practices his statement } \\
\text { by shaking his hand. }\end{array}$ \\
Scratching of \\
the nose
\end{tabular}

\section{2) Paralinguistics}

Paralinguistics communication has several contributing factors. Speed (rate), Volume, Rhythm, Pitch, Inflection, Quality and Intensity are just a few of these factors.

\section{Speed}

Speed refers to the rate of speech. A fast rate of speech and a fast rate of being able to respond have been traditionally correlated to self-assurance and composure. In this speech Jokowi mostly talks in medium or average, not too fast and not too slow.

\section{Volume}

Volume, as one of the factors of paralinguistics communication, refers to the loudness of the sound. The volume of Jokowi's speech is not too weak, but when he thinks that it is very important thing then his voice louder. It means that he meant that words.

\section{Rhythm}

Rhythm refers to the pattern of sound that characterizes a language, dialect or accent. The dialect of Jokowi speech is Javanese dialect because he is a Javanese. Mostly in his speech there is Javanese dialect. That is the way he delivered his speech.

\section{Pitch}

Pitch refers to the frequency or level of a sound. The pitch of Jokowi's speech is lower pitch. It means that Jokowi has a greater credibility, maturity and authority. He is calmer and more credible.

\section{Inflection}

Inflection or vocal variety refers to variations in pitch or musical quality of the voice. In this speech Jokowi also use inflection to maintain the interest of the disputants in what he is saying.

\section{Quality}

Quality, in paralinguistics communication, usually refers to the character of the vowel sound and the distinctive tone people make when speaking. Jokowi's sound is very unique. The quality of Jokowi's sound is smooth. People can easily understand what he is saying. 
Intensity refers to the strength, power or force of the speech. Sometimes Jokowi has strength in his voice. It would make the people have to listen to that words, because that is the important thing.

Table 3. Table of paralinguistics

\begin{tabular}{|c|c|c|c|c|c|c|c|c|c|c|}
\hline No & Second & PARALINGUISTICS & Speed & Volume & Rhythm & Pitch & Inflection & Quality & Intension & Explanation \\
\hline 1 & 01: 13 & $\begin{array}{l}\text { “.. dengan ini perlu } \\
\text { saya tegaskan..” (I } \\
\text { here by declare..) He } \\
\text { state that sentence for } \\
\text { twice with normal } \\
\text { volume of sound. }\end{array}$ & & & & & & & & $\begin{array}{l}\text { He talked with } \\
\text { normal volume of } \\
\text { sound to stress the } \\
\text { main idea what he } \\
\text { wants to talk. }\end{array}$ \\
\hline 2 & $\begin{array}{l}01: 24- \\
01: 42\end{array}$ & $\begin{array}{l}\text { He makes his sound } \\
\text { volume by words to } \\
\text { words become loud }\end{array}$ & & & & & & & & $\begin{array}{l}\text { When he give one } \\
\text { important thing so } \\
\text { society there easy to } \\
\text { remind what that } \\
\text { important thing. }\end{array}$ \\
\hline 3 & $02: 30$ & He talks latterly & & & & & & & & $\begin{array}{l}\text { mediator to speak in } \\
\text { a rate. }\end{array}$ \\
\hline 4 & $02: 42$ & $\begin{array}{l}\text { His frequent of his } \\
\text { sound started lower }\end{array}$ & & & & & & & & $\begin{array}{ll}\text { Maybe His spirit } \\
\text { started to lower/ } \\
\text { tired. }\end{array}$ \\
\hline 5. & 02: 48 & $\begin{array}{l}\text { There is just like the } \\
\text { intension when he } \\
\text { said" untuk..." 'for the } \\
\text { sake of ...' }\end{array}$ & & & & & & & & $\begin{array}{l}\text { This is just like the } \\
\text { indicative of the } \\
\text { passion and level of } \\
\text { commitment to the } \\
\text { speaker. } \\
\text { Character of }\end{array}$ \\
\hline 6. & $04: 49$ & $\begin{array}{l}\text { When he said word } \\
\text { "media" }\end{array}$ & & & & & & & & $\begin{array}{l}\text { language, dialect or } \\
\text { accent, because } \mathrm{He} \\
\text { is Javanese. }\end{array}$ \\
\hline 7. & $00: 37$ & $\begin{array}{l}\text { He said" nasib telah } \\
\text { ditentukan oleh } \\
\text { rakyat" 'fate is } \\
\text { decided by peoples } \\
\text { voice' clearly as his } \\
\text { emotion / passion. }\end{array}$ & & & & & & & & $\begin{array}{l}\text { That is the passion } \\
\text { and level of } \\
\text { commitment of the } \\
\text { speaker and reveals } \\
\text { the emotions behind } \\
\text { the spoken words }\end{array}$ \\
\hline 8. & $\begin{array}{l}00: 54- \\
01: 00\end{array}$ & $\begin{array}{l}\text { He told some quality } \\
\text { sentences that make } \\
\text { people roar there. }\end{array}$ & & & & & & & & $\begin{array}{l}\text { He tells the realistic } \\
\text { point on his speech } \\
\text { and getting feedback } \\
\text { from trusted persons. }\end{array}$ \\
\hline 9. & $01: 13$ & He talked slowly & & & & & & & & $\begin{array}{l}\text { His fast rate in } \\
\text { speaking becomes } \\
\text { slower. }\end{array}$ \\
\hline
\end{tabular}

\section{3) Proxemics}

Proxemics refers to the amount of space around a person or between two persons. Communicating with others by virtue of the relative positioning of your bodies is called Proxemic communication. Tolentino (1966) classified that there are four key zones of personal space around our bodies. According to this classification Jokowi's speech is the third one "Social-consultative: four to twelve feet: formal transactions." Jokowi delivered his speech in the stage so, all of the audience able to hear and see him.

He is standing up around two meters from the stage where his speech takes place. I think it's normal and with the distance not too close and not too far from the listener. That distance is accordance with the amount of people there. 


\section{4) Oculesics}

The study of eye contact in nonverbal communication is called "Oculesics". There is eye contact when two people look at each other's eyes at the same time. In this speech Jokowi spread the eye contact, he looked at all the audience. It is important to keep eye contact when doing speech. We may look confidence.

In this part, Jokowi use eye contact regularly. He saw all people, audiences there, for a few seconds that he saw his speech paper that he hold.

His good eye contact as the evidence that he is secure, competence, trustworthy and may confidence. He is full of confidence when standing there and delivered his speech, firmly without nervous.

He makes his eye contact such as in time; 00:18, 00:30, 00:37, etc actually Jokowi used his speech paper just as a note reminder, he had memorized his material in his mind, so he can make good eye contact with his listener. This is as an informal speech.

\section{Findings}

Jokowi's speech uses kinesics in his speech, as we realized that kinesic divided into 5: emblems (1), illustrators (2), affect displays (3), regulators (4) and adaptors (5).

Table 5. Recapitulation of Kinesics

\begin{tabular}{|c|c|c|c|c|c|c|c|c|}
\hline No & Speech & 1 & 2 & 3 & 4 & 5 & from & $\%$ \\
\hline 1 & September 19th 2013 & 2 & - & 3 & - & 3 & 9 & \\
\hline 2 & 9th July 2014 & 4 & - & 4 & - & 3 & 9 & \\
\hline 3 & 22 July 2014 & 5 & - & - & - & - & 5 & \\
\hline 4 & 22 Agustus 2014 & 1 & 2 & - & - & 1 & 4 & \\
\hline 5 & 22 September 2014 & 4 & - & 1 & 1 & - & 6 & \\
\hline 6 & 20 Oktober 2014 & 11 & - & 1 & - & - & 12 & \\
\hline 7 & 20 October 2014 & 3 & 9 & 5 & 23 & 1 & 44 & \\
\hline \multirow[t]{2}{*}{-} & & 30 & 11 & 14 & 24 & 8 & 89 & \\
\hline & & $33.9 \%$ & $12.8 \%$ & $15.9 \%$ & $27.9 \%$ & $9.5 \%$ & & \\
\hline
\end{tabular}

Jokowi mostly uses Non Verbal Emblems (33.9\%) in his speech where emblems are defined as body movements that substitute for words and phrases. However, the meaning of emblems is usually varied from culture to culture; in this case Jokowi is influenced by Javanese culture. He also uses regulators which are nonverbal messages that control, regulate or influence the flow and pace of communication. Holding his hand, or Nodding of the head to indicate understanding or to encourage or appreciate the party, raising a finger or hand to indicate the desire to speak its $27.9 \%$ which means that Jokowi does the non verbal kinesics in his speech.

Paralinguistics refers to the nonverbal vocal expressions of a person. According to experts, voice set and vocalization are the two dimensions of the voice. Voice set is the information that may be gathered from the sound of the voice such as gender, maturity and mindset. On the other hand, vocalizations are non-word sounds that usually reveal emotion such as laughing, crying, and yawning. Jokowi delivers his speech higher to deliver the spirit of "to work hard", no collusion, no corruption, and respect each other among party.

He wants all profession work hard, so he says loudly also, when he says people in the "capital" of Jakarta, loudly "To work together", he says in loudly voice. "To be strong nation", he wants people to know about it. He expresses his emotion in saying "prosperous". Jokowi says the word "to grade" loudly. Jokow's pitches is low when he say "But". He shows confidence in saying "Don't Think", and his emotion appears. He says "peaceful nation" in loud voice. To say "But", he decrease his pitches again, in lower pitches he says "don't think". Saying "to be big nation", he shows his confidence and full power in his speech. Even he has a very strong in his Javanese dialect still his Paralinguistics made an effect to his massage. To do pause for a while, it doesn't mean he forgot his word, but to get the audience's attention. His strong intention he shows by using his pointing finger etc.

Non-verbal communication is one of the key aspects of communication. Non-verbal communication can even alter a verbal message through mimics, gestures and facial expressions, particularly when people do not speak the same language. It is important to know and use non-verbal aspects when we communicate with someone or when we deliver our speech in front of people. From the data above we can conclude that Jokowi use non-verbal aspects in his speech. That aspects make him be confidence. Some of that aspect made him looked so nervous. 
But he can balance by laughing or grin to make the speech not monotonous, to attract the audience. He speaks mostly slow that would make the audience easier to understand the speech. Everybody has their own style in deliver their speech, and above is Jokowi's style in deliver his speech.

After analyzing the speech, the characteristics of Jokowi's non verbal language in his speech can be drawn as follows:

Kinesics
He always uses his pointing finger, to show the serious intention
Always starts with a religious greeting, with a big smile, to show his friendly character,
sometimes using. Use hands. Using emblems to show small, or big, fist hand to show
intention, and spirit, use regulators to move the topic.

Proxemics Mostly in 5-12 inches from his audiences, but quite close if it is an interview.

Oculesics Always made a eye contact, on his audiences regularly

Paralinguistics Always take a pause, to get the attention, Repeat the sentence

Do a strong voice for an important massage and make a clear Voice in a Javanese dialect.

1) Speed: Jokowi's speech total words are 768 and duration 10 minutes 24 seconds. Speaking rate $=$ total words $/$ minutes $=768 / 10=76,8$ words per minute.

2) Volume: The volume of Jokowi's speech is good. But in his speech there are show in the first speech when he forget to mention her partner Jusuf Kalla. And in his speech sometimes Jokowi's voice is slowly and sometimes he give stress in his speech.

3) Rhythm: Jokowi's speech Rhythm is Javanese. There are often he used dialect Java in his speech like that legato in Java. And I think there is to impact in his voice to delivered his speech.

4) Pitch: Jokowi's uses lower pitch but in several part in his speech he do 'strees (penekanan) that powerful and louder.

5) Intensity: Jokowi used intensity in some of his words to emphasize them.

\section{Context of speech: is held at the 22 September 2014:}

After Jokowi inducted into President. AT Pelabuhan Sunda Kelapa, Jakarta Utara, on the Occasion of Jokowi's victory speech and Jusuf Kalla on election as President and Vice President the audiences are Public or residents of Jakarta ans Speech duration: 6 minutes 37 second

Choosing Phinisi with the name "Heart Buana Faithful", nor is it a coincidence. The name was also implies that in Sailing with skipper Phinisi Jokowi-JK "while maintaining fidelity to the heart of the universe", to build without destroying the globe. Phinisi Indonesia with captain Jokowi-JK will start shipping on October 20th. There is still time to prepare all the equipment. Jokowi-JK must select an agile and skilled sailors were able to take decisions in difficult times. Sailors must be guaranteed to have a single loyalty only to the helmsman. Sailors must be guaranteed only run agenda captain, has no

\section{Suggestions}

To make a good speech, please apply non verbal language to strengthen the massage delivered, and smile to release audiences even if the messages talk about serious issues. The nonverbal language should support the verbal language.

\section{References}

Chandler, D. (2002). The Basics Semiotics. USA and Canada: Rouledge.

Cobley, P. (2001). The Rouledge Companion to Semiotics And Linguistics. London: Rouledge.

Eco. (1976). Semiotics Discussion. London: University of London.

Malmkjaer, K. (1991). The Linguistics Ecyclopedia. London and New York: Routledge.

New Lexicon Webster's Encyclopedia Dictionary of the English Language. (1993). Lexicon: USA.

Sausssure, F. (1974). Course in General Linguistics. London: Fontana.

Shi, Y., \& Fan, S. (2010). The International Journal: An Analysis of Non-Verbal Behaviour in Intercultural Communication. Retrieved from http://www.aaref.com.au 
Tolentino, R. S. (2011). The Use of Non-Verbal Communication in Mediation. Retrieved from http://barcouncil.org.my/conference1/pdf/3.NONVERBALCOMMUNICATIONANDMEDIATION.pdf

Wang, H. (2009). Nonverbal Communication and the Effect on Interpersonal Communication. Retrieved from www.ccsenet.org/jounal.html

\section{Copyrights}

Copyright for this article is retained by the author(s), with first publication rights granted to the journal.

This is an open-access article distributed under the terms and conditions of the Creative Commons Attribution license (http://creativecommons.org/licenses/by/3.0/). 